\title{
Microevolution of Pseudomonas aeruginosa in cystic fibrosis lungs
}

\author{
Nina Cramer", Jens Klockgether, Colin F Davenport, Burkhard Tümmler \\ From 50th Workshop for Pediatric Research \\ Gottingen, Germany. 20-21 March 2014
}

The chronic airway infections with Pseudomonas aeruginosa determine disease outcome in most individuals with cystic fibrosis $(\mathrm{CF})$. We have collected serial $P$. aeruginosa isolates in half year intervals from all $35 \mathrm{CF}$ patients at our local CF clinic who became colonized with $P$. aeruginosa in the 1980s. The microevolution of $P$. aeruginosa in CF lungs was investigated in the six patients with the mildest and most severe course of their chronic $P$. aeruginosa infection.

Serial isolates were genotyped with a customized microarray. Isolates of the initially colonizing clone were then subjected to whole genome sequencing by SOLiD5500 technology. Nucleotide variations compared to the PA14 genome were extracted, filtered, annotated and used for the reconstruction of clades. The 250 sequenced bacterial isolates were characterized in mutation rates, morphology, motility and secretion of virulence effectors.

Exopolysaccharide biosynthesis, antimicrobial resistance and global regulators of lifestyle and metabolism are the most common functional categories whose genes were hit by mutations in the CF lungs. Microevolution was not uniform. The $P$. aeruginosa clone inhabiting severely affected lungs repetitively generated descendants with stop mutations or drastic amino acid changes in key genes of lifestyle, but these loss-of-function mutants were not recovered at later time points. In contrast, $P$. aeruginosa clones predominantly acquired benign amino acid substitutions in patients who maintained a normal function of their chronically colonized lungs for up to 30 years.

Modes of microevolution of $P$. aeruginosa in CF lungs are associated with the severity of the chronic lung infection.

Supported by DFG (SFB900) and Christiane Herzog Stiftung.

Klinik für Pädiatrische Pneumologie, Allergologie und Neonatologie,

Medizinische Hochschule Hannover, Germany
Published: 11 September 2014

doi:10.1186/2194-7791-1-S1-A28

Cite this article as: Cramer et al:: Microevolution of Pseudomonas aeruginosa in cystic fibrosis lungs. Molecular and Cellular Pediatrics 2014 1(Suppl 1):A28.

\section{SpringerOpen $^{\odot}$}

(C) 2014 Cramer et al; licensee Springer This is an Open Access article distributed under the terms of the Creative Commons Attribution License (http://creativecommons.org/licenses/by/2.0), which permits unrestricted use, distribution, and reproduction in any medium, provided the original work is properly cited.
Submit your manuscript to a SpringerOpen ${ }^{\circ}$ journal and benefit from:

- Convenient online submission

- Rigorous peer review

- Immediate publication on acceptance

- Open access: articles freely available online

- High visibility within the field

- Retaining the copyright to your article

Submit your next manuscript at $>$ springeropen.com 